\title{
Cycloaddition of trifluoromethyl azafulvenium methides: synthesis of new trifluoromethylpyrrole-annulated derivatives
}

\author{
Cláudio M. Nunes ${ }^{\mathrm{a}}$, Manuela Ramos Silva ${ }^{\mathrm{b}}$, Ana Matos Beja ${ }^{\mathrm{b}}$, Rui Fausto ${ }^{\mathrm{a}}$, Teresa M. V. D. Pinho e Melo ${ }^{\mathrm{a}, *}$ \\ a Department of Chemistry, University of Coimbra, 3004-535 Coimbra, Portugal \\ ${ }^{\mathrm{b}}$ Department of Physics, University of Coimbra, 3004-516 Coimbra, Portugal
}

\section{A R T I C L E I N F O}

\section{Article history:}

Received 12 October 2009

Revised 6 November 2009

Accepted 10 November 2009

Available online 13 November 2009

\section{Keywords:}

Trifluoromethylpyrroles

1,3-Dipoles

1,7-Dipoles

Azafulvenium methides

Azomethine ylides

$[8 \pi+2 \pi]$ Cycloaddition

1,3-Dipolar cycloaddition

1,7-Electrocyclization

Microwave

\begin{abstract}
A B S T R A C T
The chemistry of trifluoromethyl azafulvenium methides was explored leading to a new route to trifluoromethylpyrrole-annulated systems. The first evidence of azafulvenium methides acting as 1,3-dipoles is reported. These azafulvenium methides showed site selectivity in the reaction with strong electrondeficient dipolarophiles leading exclusively to 1,3-cycloadducts. In the cycloaddition with less-activated dipolarophiles 1,7 -cycloadducts resulting from $[8 \pi+2 \pi]$ cycloaddition are also formed. FMO analysis of the cycloaddition reactions allowed the rationalization of the observed selectivity.
\end{abstract}

(C) 2009 Elsevier Ltd. All rights reserved.
Pyrroles represent an important class of heterocycles due to their broad distribution in nature as constituents of the framework of a range of natural products, and also of synthetic bioactive molecules. ${ }^{1}$ Polypyrroles also find applications in materials science, nonlinear optics, and supramolecular chemistry as molecular sensors and devices. ${ }^{2}$ On the other hand, the development of routes to heterocyclic compounds bearing a trifluoromethyl group has received much attention, since the introduction of this group with unique stereoelectronic properties in organic molecules often improves their biological activity. The influence of the trifluoromethyl group on the physiological activity is usually concerned with the increasing lipophilicity, leading to the improvement of their transport characteristics in vivo. The high electronegativity of the $\mathrm{CF}_{3}$ group results in a quite different electron-density distribution and significantly changes the reactivity of the molecules. There are only a few examples of trifluoromethyl-containing pyrroles, however, some of these compounds have demonstrated important insecticidal action and mitochondrial uncoupling activity. ${ }^{3}$

Aza- and diazafulvenium methide systems $\mathbf{1}$ and $\mathbf{2}$ are reactive intermediates which can be considered 'higher-order' azomethine ylides and azomethine imines, respectively. These systems, in principle, could act as $4 \pi 1,3$-dipoles or as $8 \pi 1$,7-dipoles. However, the

\footnotetext{
* Corresponding author. Tel.: +351239854475.

E-mail address: tmelo@ci.uc.pt (T.M.V.D. Pinho e Melo).
}

derivatives studied up to now showed the reactivity pattern expected for 1,7-dipoles. ${ }^{4-7}$ It has been demonstrated that aza- and diazafulvenium methides are very versatile building blocks for the synthesis of functionalized pyrroles and pyrazoles. These extended 1,7-dipoles are generated from 2,2-dioxo- $1 \mathrm{H}, 3 \mathrm{H}$-pyrrolo[1,2-c]thiazoles (e.g., 3) or 2,2-dioxo- $1 \mathrm{H}, 3 \mathrm{H}$-pyrazolo[1,5-c]thiazoles (e.g., 4) by thermal extrusion of sulfur dioxide and participate in pericyclic reactions, namely sigmatropic $[1,8] \mathrm{H}$ shifts and 1,7-electrocyclizations, giving $N$-vinyl- or $C$-vinyl pyrroles and pyrazoles. $^{4-7}$ Azafulvenium methides $\mathbf{5}$ generated under microwave irradiation from the corresponding 2,2-dioxo- $1 \mathrm{H}, 3 \mathrm{H}$-pyrrolo[1,2-c]thiazoles can be intercepted in $[8 \pi+2 \pi]$ cycloadditions. ${ }^{7}$ Diazafulvenium methides 6 also behave as $8 \pi$ 1,7-dipoles under either microwave irradiation or conventional heating, affording the corresponding 1,7-cycloadducts $\mathbf{8}$ (Scheme 1).,6,7

In this context, we decided to further explore the chemistry of azafulvenium methides in order to find a new route to trifluoromethylpyrrole-annulated systems.

One approach to construct trifluoromethylated compounds, including 7-(trifluoromethyl)-1H,3H-pyrrolo[1,2-c]thiazoles, is the use of halogen-containing building blocks as starting reagents. ${ }^{8}$ In fact, it has been reported that the reaction of 4-ethyloxy-1,1,1-trifluorobut-3-ene-2-one $(\mathbf{9})^{9}$ with thiazolidine-4-carboxylic acid (10a) gives a mixture of pyrrolo[1,2-c]thiazoles, 7-(trifluoromethyl)$1 \mathrm{H}, 3 \mathrm{H}$-pyrrolo[1,2-c]thiazole (11a) obtained as the major product, 


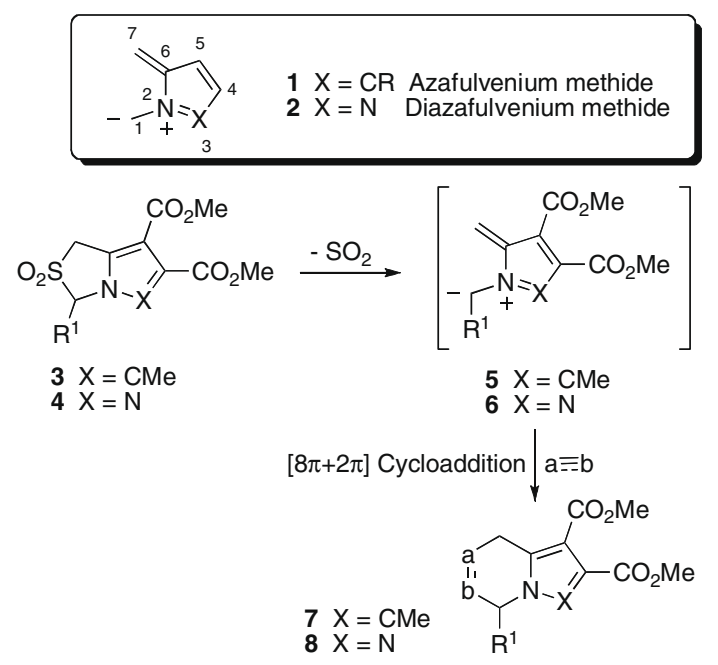

Scheme 1. $[8 \pi+2 \pi]$ cycloaddition of aza- and diazafulvenium methides.

together with the formation of $1 H, 3 H$-pyrrolo[1,2-c]thiazole 12 (Scheme 2). ${ }^{10}$

In order to prepare our target 2,2-dioxo-7-(trifluoromethyl)$1 \mathrm{H}, 3 \mathrm{H}$-pyrrolo[1,2-c]thiazoles we looked into this reaction of ketone $\mathbf{9}$ with thiazolidines. The reaction of thiazolidines $\mathbf{1 0}$ with 4-ethyloxy-1,1,1-trifluorobut-3-ene-2-one (9) gave the expected 1-[(E)-4,4,4-trifluoro-3-oxo-1-butenyl]thiazolidines 13 in good yield. Two rotamers are observed in the ${ }^{1} \mathrm{H}$ NMR and ${ }^{13} \mathrm{C}$ NMR spectra of compounds 13 recorded at ambient temperature, but the spectra recorded at $100{ }^{\circ} \mathrm{C}$ showed a single set of signals. It is important to notice that $\mathbf{1 3 b}$ was obtained in a diastereoselective fashion. This selectivity can be explained considering that 2unsubstituted-1,3-thiazolidine-4-carboxylates can undergo selective inversion at $\mathrm{C}-2$ through a mechanism involving the opening of the ring with the formation of the corresponding Schiff base, but the N-protection of the 2-substituted-1,3-thiazolidine-4-carboxylates prevents this epimerization and allows the isolation of pure diastereoisomers. ${ }^{11}$

We observed that by changing the solvent from dichloromethane to acetonitrile, the cyclization of enamines $\mathbf{1 3}$ gives almost exclusively 7 -(trifluoromethyl)- $1 H, 3 H-1 H, 3 H$-pyrrolo[1,2-c]thiazoles 11. The structure of product $\mathbf{1 1 b}$ was determined by X-ray crystallography allowing to unambiguously establish the stereochemistry as being $R$ configuration (see Supplementary data). The diffraction spectrum of the powder was also obtained and was identical to the simulation of the diffraction spectrum for compound 11b based on the X-ray diffraction data collected from the single crystal. Therefore, we could confirm that 1-[(E)-4,4,4-trifluoro-3-oxo-1-butenyl]thiazolidines $\mathbf{1 3 b}$ was obtained as a single stereoisomer and underwent cyclization to give chiral $(R)-3$-phenyl-7-(trifluoromethyl)-1H,3H-pyrrolo[1,2-c]thiazole 11b $[\alpha]_{\mathrm{D}}$ +159 ) in $85 \%$ yield (Scheme 3 ).

The 2,2-dioxo-7-(trifluoromethyl)-1H,3H-pyrrolo[1,2-c]thiazoles 14 were prepared in good yields by catalytic oxidation ${ }^{12}$ of 11 (Scheme 3).

Microwave irradiation of 2,2-dioxo-7-trifluoromethyl-1H,3Hpyrrolo[1,2-c]thiazoles 14 led to the generation of the new inter-

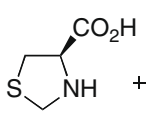

$10 a$

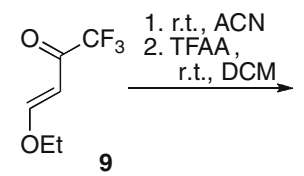

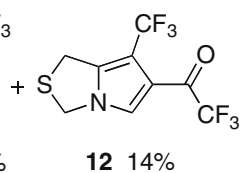

Scheme 2. Synthesis of 7-(trifluoromethyl)-1H,3H-pyrrolo[1,2-c]thiazoles. ${ }^{10}$<smiles>CCOC=CC(=O)C(F)(F)F</smiles>

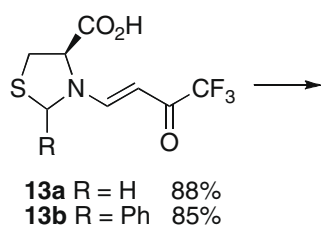<smiles>[R]C1SCc2c(C(F)(F)F)ccn21</smiles><smiles>[R]C1n2ccc(C(F)(F)F)c2C[S@]1(=O)[O-]</smiles>

$\begin{array}{ll}\text { 11a } R=H & 78 \% \\ 11 b R=P h & 85 \%\end{array}$

14a $\mathrm{R}=\mathrm{H} \quad 73 \%$ 14b $\mathrm{R}=\mathrm{Ph} 70 \%$

Scheme 3. Synthesis of 2,2-dioxo-7-(trifluoromethyl)-1H,3H-pyrrolo[1,2-c]thiazoles 14.

mediate trifluoromethyl azafulvenium methides $\mathbf{1 5}$ which could be trapped by dipolarophiles. We observed the first evidence of azafulvenium methides acting as 1,3-dipole leading to 1,3-dipolar cycloadducts. In fact, azafulvenium methides 15 react with $N$ phenylmaleimide affording cycloadducts $\mathbf{1 6}^{13}$ resulting from the addition across the 1,3-position, and no 1,7-cycloadducts could be detected.

In the case of trifluoromethyl azafulvenium methide 15b the formation of $C$-vinylpyrrole $\mathbf{1 7}$ as a competitive reaction was also observed. In the absence of dipolarophile the $C$-vinylpyrrole $\mathbf{1 7}$ was obtained exclusively in $64 \%$ yield (Scheme 4 ). The formation of C-vinylpyrroles from 2,2-dioxo-1 $\mathrm{H}, 3 \mathrm{H}$-pyrrolo[1,2-c]thiazole-

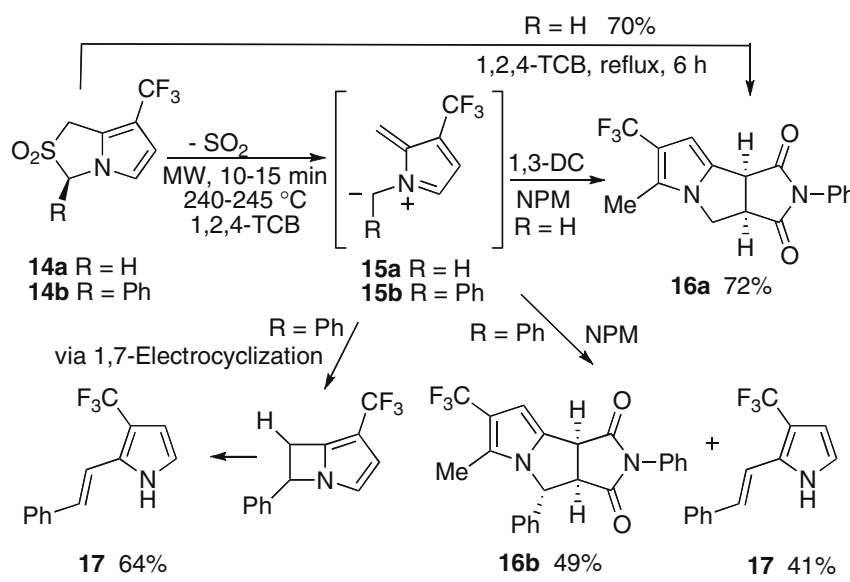

Scheme 4. Pericyclic reactions of trifluoromethyl azafulvenium methides.

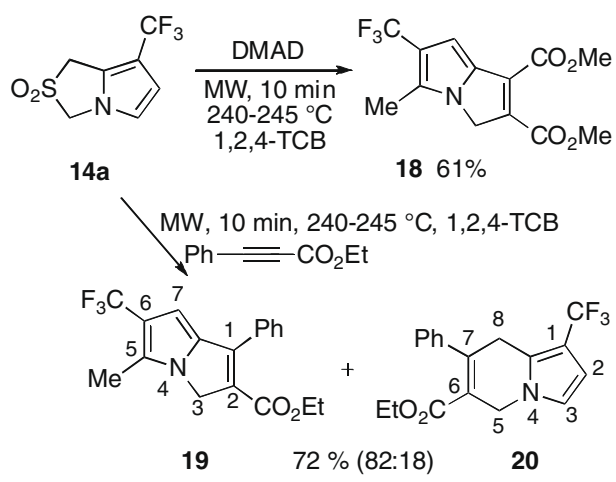

Scheme 5. Cycloaddition reactions of $\mathbf{1 5 a}$. 
Table 1

Frontier orbital energies (eV) for 15a and different dipolarophiles at AM1, PM3 and HF/6-31G(d) theoretical levels

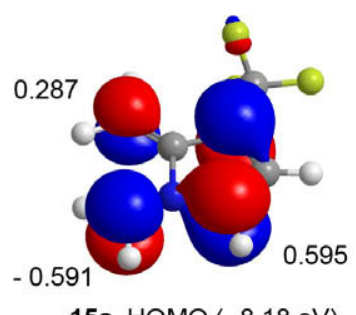

15a $\operatorname{HOMO}(-8.18 \mathrm{eV})$

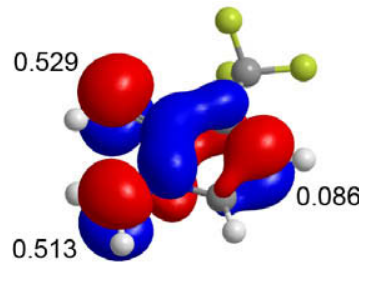

15a LUMO (- $1.44 \mathrm{eV})$

\begin{tabular}{|c|c|c|c|c|c|c|c|c|c|}
\hline & \multicolumn{3}{|c|}{ HOMO } & \multicolumn{3}{|c|}{ LUMO } & \multicolumn{3}{|c|}{$\Delta E(\mathrm{I})^{\mathrm{a}}-\Delta E(\mathrm{II})^{\mathrm{b}}$} \\
\hline & AM1 & PM3 & $\mathrm{HF} / 6-31 \mathrm{G}(\mathrm{d})$ & AM1 & PM3 & $\mathrm{HF} / 6-31 \mathrm{G}(\mathrm{d})$ & AM1 & PM3 & $\mathrm{HF} / 6-31 \mathrm{G}(\mathrm{d})$ \\
\hline $15 a$ & -7.83 & -8.19 & -6.15 & -1.24 & -1.44 & 1.40 & - & - & - \\
\hline NPM & -11.61 & -11.49 & -11.52 & -1.25 & -1.22 & 1.51 & 3.78 & 3.08 & 5.26 \\
\hline DMAD & -11.96 & -11.83 & -11.72 & -0.51 & -0.36 & 3.01 & 3.40 & 2.56 & 3.96 \\
\hline Ethyl 3-phenylpropiolate & -9.68 & -9.72 & -8.94 & -0.67 & -0.66 & 2.25 & 1.28 & 0.75 & 2.02 \\
\hline
\end{tabular}

Isosurface of HOMO and LUMO of $\mathbf{1 5 a}$ and calculated MO coefficients (PM3) at the reactive sites C1, C3, and C7 are also presented.

a $\Delta E(\mathrm{I})=\mathrm{HOMO}_{\text {dipole }}-\mathrm{LUMO}_{\text {dipolarophile }}$

b $\Delta E(\mathrm{II})=\mathrm{HOMO}_{\text {dipolarophile }}-\mathrm{LUMO}_{\text {dipole }}$

6,7-dicarboxylates via 1,7-electrocyclization of the azafulvenium methide intermediates has been observed previously. ${ }^{5}$

The generation of trifluoromethyl azafulvenium methides $\mathbf{1 5}$ is also possible under conventional thermolysis. Heating at reflux a solution of $1 \mathrm{H}, 3 \mathrm{H}$-pyrrolo[1,2-c]thiazole $\mathbf{1 4 a}$ and $\mathrm{N}$-phenylmaleimide in 1,2,4-trichlorobenzene for $6 \mathrm{~h}$ leads to the formation of 1,3-cycloadduct 16a in 70\% yield (Scheme 4). This result is an indication that the generation of 5-trifluoromethyl azafulvenium methides $\mathbf{1 5}$ is easier than the generation of azafulvenium methide derivatives previously studied, which required sealed tube thermolysis, flash vacuum pyrolysis, or microwave irradiation. $^{4,6}$

The trifluoromethyl azafulvenium methide 15a generated from $1 H, 3 H$-pyrrolo[1,2-c] thiazole 14a under microwave irradiation also reacts with dimethylacetylene dicarboxylate to give the corresponding 1,3-dipolar cycloadduct $\mathbf{1 8}$ in $61 \%$ yield. The reaction with ethyl 3-phenylpropiolate gives a mixture of 1,3- and 1,7-cycloadducts 19 and 20, respectively, in $72 \%$ overall yield with a ratio of 82:18 (Scheme 5). The structural assignment of these cycloadducts was based on a NOESY spectrum. The spectrum of compound 19 shows connectivity between the phenyl group and the pyrrolic proton and connectivity between the methyl group and the methylenic protons can also be observed. In the NOESY spectrum of compound 20, connectivity between methylenic protons $\mathrm{H} 5$ and the pyrrolic proton $\mathrm{H} 3$ is observed. On the other hand, the methylenic protons $\mathrm{H} 8$ are correlated with the phenyl group, which is in agreement with the proposed structure. No reaction was observed using bis(trimethylsilyl)acetylene, dimethyl azodicarboxylate, or $\mathrm{N}$-benzylidenebenzenesulfonamide as dipolarophiles.

The FMO analysis for cycloaddition reactions of trifluoromethyl azafulvenium methide $\mathbf{1 5 a}$ indicated that the $\mathrm{HOMO}_{\text {dipole }}$ $\mathrm{LUMO}_{\text {dipolarophile }}$ is the dominant interaction for strong electrondeficient dipolarophiles. In the $\mathrm{HOMO}_{\text {dipole }}$ controlled reaction, the reactive sites $\mathrm{C} 1$ and $\mathrm{C} 3$ of the dipole have the higher orbital coefficients indicating that the 1,3-cycloaddition should take place exclusively as observed experimentally. For the less-activated dipolarophiles such as ethyl 3-phenylpropiolate, the $\mathrm{LUMO}_{\text {dipole }^{-}}$ $\mathrm{HOMO}_{\text {dipolarophile }}$ interaction must also be considered. The LUMO of the azafulvenium methide 15a is characterized by having the reactive sites $\mathrm{C} 1$ and $\mathrm{C7}$ with the highest orbital coefficients, favor- ing the 1,7-cycloaddition. This rationalization explains the formation of both 1,3-cycloadduct and 1,7-cycloadduct when the reaction is promoted with ethyl 3-phenylpropiolate (Table 1 and Supplementary data).

Storr et al. also carried out molecular orbital calculations (PM3) to estimate the atomic orbital coefficients and the energy of the HOMO and LUMO of azafulvenium methide $5\left(\mathrm{R}^{1}=\mathrm{H}\right){ }^{4}$ The data suggested that the addition of azafulvenium methide $\mathbf{5}$ to DMAD should occur via 1,3-dipolar cycloaddition and the reaction with electron-rich dipolarophiles would be via $[8 \pi+2 \pi]$ mode. This prediction suggests that this dipole $\mathbf{5}$ should have the same chemical behavior toward dipolarophiles as the one shown by trifluoromethyl azafulvenium methide (15a). However, we observed that azafulvenium methide $\mathbf{5}\left(\mathrm{R}^{1}=\mathrm{H}\right)$ shows site selectivity giving only addition across the 1,7-positions with both electron-rich and electron-poor dipolarophiles. ${ }^{7}$ This selectivity can be explained considering that steric effects play an important role. In fact, dipole $\mathbf{5}$ has a methyl substituent at C3 whereas the C3 position of azafulvenium methide 15a is unsubstituted.

In summary, we have described the generation of new transient trifluoromethyl azafulvenium methides and their use as building blocks for the construction of trifluoromethylpyrrole derivatives. The first evidence of azafulvenium methides acting as 1,3-dipoles is reported.

\section{Acknowledgments}

Thanks are due to FCT (PTDC/QUI/64470/2006 and SFRH/BD/ 28844/2006) and FEDER for financial support. We acknowledge the Nuclear Magnetic Resonance Laboratory of the Coimbra Chemical Centre (www.nmrccc.uc.pt), University of Coimbra, for obtaining the NMR data.

\section{Supplementary data}

Synthetic procedures and characterization data for all compounds. X-ray crystal structure of compound 11b and computational data are available. Supplementary data associated with this article can be found, in the online version, at doi:10.1016/ j.tetlet.2009.11.033. 


\section{References and notes}

1. For reviews on pyrrole, see: (a) Sundberg, R. J.. In Comprehensive Heterocyclic Chemistry; Katritzky, A. R., Rees, C. W., Scriven, E. F. V., Eds.; Pergamon: Oxford, 1996; Vol. 2, pp 119-206; (b) Trofimov, B. A.; Sobenina, L. N.; Demenev, A. P.; Mikhaleva, A. L. Chem. Rev. 2004, 104, 2481-2506; (c) Furstner, A. Angew. Chem., Int. Ed. 2003, 42, 3582-3603.

2. (a) Baumgarlen, M.; Tyulyulkor, N. Chem. Eur. J. 1998, 4, 987-989; (b) Higgins, S. J. Chem. Soc. Rev. 1997, 26, 247-258; (c) Anzenbacher, P., Jr.; Nishiyabu, R.; Palacios, M. A. Coord. Chem. Rev. 2006, 250, 2929-2938; (d) Jeppesen, J. O.; Becher, J. Eur. J. Org. Chem. 2003, 3245-3266.

3. Selected examples: (a) Black, B. C.; Hollingworth, R. M.; Ahammadsahib, K. Y.; Kukel, C. D.; Donovan, S. Pestic. Biochem. Physiol. 1994, 50, 115-128; (b) Zanatta, N.; Schneider, J. M. F. M.; Schneider, P. H.; Wouters, A. D.; Bonacorso, H. G.; Martins, M. A. P.; Wessjohann, L. A. J. Org. Chem. 2006, 71, 6996-6998; (c) Dou, G.; Shi, C.; Shi, D. J. Comb. Chem. 2008, 10, 810-813; (d) Uno, H.; Inoue, K.; Inoue, T.; Fumoto, Y.; Ono, N. Synthesis 2001, 2255-2258; (e) Fitzgerald, J. P.; Nanda, H.; Fitzgerald, P.; Yee, G. T. J. Org. Chem. 2000, 65, 2222-2224; (f) Funabiki, K.; Ishihara, T.; Yamanaka, H. J. Fluorine Chem. 1995, 71, 5-7.

4. (a) Sutcliffe, O. B.; Storr, R. C.; Gilchrist, T. L.; Rafferty, P.; Crew, A. P. A. Chem Commun. 2000, 675-676; (b) Sutcliffe, O. B.; Storr, R. C.; Gilchrist, T. L.; Rafferty, P. J. Chem. Soc., Perkin Trans. 1 2001, 1795-1806.

5. (a) Pinho e Melo, T. M. V. D.; Soares, M. I. L.; Rocha Gonsalves, A. M. d'A.; McNab, H. Tetrahedron Lett. 2004, 45, 3889-3893; (b) Pinho e Melo, T. M. V. D.; Soares Maria, I. L.; Rocha Gonsalves, A. M. d'A.; Paixão, J. A.; Matos Beja, A.; Ramos Silva, M. J. Org. Chem. 2005, 70, 6629-6638; (c) Pinho e Melo, T. M. V. D.; Soares, M. I. L.; Nunes, C. M. Tetrahedron 2007, 63, 1833-1841; (d) Soares, M. I L.; Lopes, S. M. M.; Cruz, P. F.; Brito, R. M. M.; Pinho e Melo, T. M. V. D. Tetrahedron 2008, 64, 9745-9753.

6. (a) Pinho e Melo, T. M. V. D.; Soares, M. I. L.; Rocha Gonsalves, A. M. d'A. Tetrahedron Lett. 2006, 47, 791-794; (b) Pinho e Melo, T. M. V. D.; Soares, M. I. L.; Nunes, C. M.; Paixão, J. A.; Matos Beja, A.; Ramos Silva, M. J. Org. Chem. 2007, $72,4406-4415$
7. Soares, M. I. L.; Pinho e Melo, T. M. V. D. Tetrahedron Lett. 2008, 49, 4889-4893.

8. Druzhinin, S. V.; Balenkova, E. S.; Nenajdenko, V. G. Tetrahedron 2007, 63, 7753 7808.

9. Hojo, M.; Masuda, R.; Ohada, E. Tetrahedron Lett. 1989, 30, 6173-6176.

10. Andrew, R. J.; Mellor, J. M. Tetrahedron 2000, 56, 7267-7272.

11. (a) Györgydeák, Z.; Kajtár-Peredy, M.; Kajtár, J.; Kajtár, M. Liebigs Ann. Chem. 1987, 927-934; (b) Benedini, F.; Ferrario, F.; Sala, A.; Sala, L.; Soresinetti, P. A. J. Heterocycl. Chem. 1994, 31, 1343-1347; (c) Lázár, L.; Fülöp, F. Eur. J. Org. Chem. 2003, 3025-3042; (d) Pinho e Melo, T. M. V. D.; Soares, M. I. L.; Barbosa, D. M.; Rocha Gonsalves, A. M. d'A.; Paixão, J. A.; Beja, A. M.; Ramos Silva, M.; Alte da Veiga, L. Tetrahedron 2000, 56, 3419-3424; (e) Pinho e Melo, T. M. V. D.; Soares, M. I. L.; Rocha Gonsalves, A. M. d'A.; Paixão, J. A.; Beja, A. M.; Ramos Silva, M.; Alte da Veiga, L.; Costa Pessoa, J. J. Org. Chem. 2002, 67, 4045-4054; (f) Pinho e Melo, T. M. V. D.; Gomes, C. S. B.; Rocha Gonsalves, A. M. d'A.; Paixão, J. A.; Beja A. M.; Ramos Silva, M.; Alte da Veiga, L. Tetrahedron 2002, 58, 5093; (g) Pinho e Melo, T. M. V. D.; Santos, C. I. A.; Rocha Gonsalves, A. M. d'A.; Paixão, J. A.; Beja, A. M. Tetrahedron 2004, 60, 3949-3955; (h) Pinho e Melo, T. M. V. D.; Lopes Susana, M. M.; Rocha Gonsalves, A. M. d'A.; Kaczor, A.; Fausto, R.; Paixão, J. A.; Beja, A. M.; Ramos Silva, M. Lett. Org. Chem. 2006, 3, 820-826.

12. Using the general synthetic procedure described in: Sato, K.; Hyodo, M.; Aoki, M.; Zheng, X.-Q.; Noyori, R. Tetrahedron 2001, 57, 2469-2476.

13. (a) General procedure for cycloaddition of trifluoromethyl azafulvenium methide generated from 2,2-dioxo-7-trifluoromethyl-1H,3H-pyrrolo[1,2-clthiazoles 14: A suspension of 2,2-dioxo-7-trifluoromethyl-1 $\mathrm{H}, 3 \mathrm{H}$-pyrrolo[1,2-c]thiazoles $\mathbf{1 4}$ $(0.1 \mathrm{mmol})$ and dipolarophile (1.5-4 equiv) in 1,2,4-trichlorobenzene $(0.5 \mathrm{~mL})$ was irradiated in the microwave reactor (CEM Focused Synthesis System, Discover S-Class) with the temperature set to $240{ }^{\circ} \mathrm{C}$ for $10 \mathrm{~min}$ under stirring. After cooling to room temperature, the mixture was purified by flash chromatography with $n$-hexane to remove 1,2,4-trichlorobenzene followed by elution with a mixture of ethyl acetate and $n$-hexane; (b) Stereochemistry assignment of $\mathbf{1 6 b}$ was based on the estimated dihedral angle between $\mathrm{H} 4$ and $\mathrm{H} 3 \mathrm{a}\left(102.0^{\circ}\right)$, the coupling of which could not be detected in the ${ }^{1} \mathrm{H}$ NMR spectrum (see Supplementary data). 